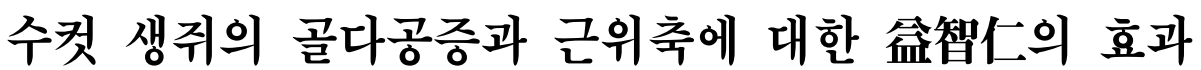

\author{
김형준 ${ }^{1}$, 안상현 ${ }^{2}$, 박선영 ${ }^{3}$ \\ ${ }^{1}$ 세명대학교 부속 제천한방병원 부인 · 소아과, ${ }^{2}$ 세명대학교 한의과대학 해부학교실 \\ ${ }^{3}$ 세명대학교 한의과대학 생리학교실
}

\section{The Effects of Alpiniae Oxyphyllae Fructus on Osteoporosis and Muscle Dystrophy of Male Mice}

\author{
Hyeong-jun Kim¹, Sang-hyun Ahn², Sun-young Park ${ }^{3}$ \\ 'Dept. of Gynecology, College of Korean Medicine, Se-Myung University \\ ${ }^{2}$ Dept. of Anatomy, College of Korean Medicine, Se-Myung University \\ ${ }^{3}$ Dept. of Physiology, College of Korean Medicine, Se-Myung University
}

\begin{abstract}
Objective: To investigate the effect of Alpiniae oxyphyllae fructus (AOF) on the alleviation of musculoskeletal disorders caused by aging, we conducted experiments on osteoporosis and muscle atrophy.

Methods: The experimental group was classified into a control group, aging-elicited (AE) group and AOF group. The control group comprised 8-week-old Institute of Cancer Research (ICR) mice. The AE and AOF groups were ICR mice at 50 weeks of age. For the AE group, $10 \mathrm{~mL}$ of distilled water was administered once a day for 180 days without any treatment. An AOF extract $(0.54 \mathrm{~g} / \mathrm{kg})$ was dissolved in distilled water and administered to the mice in the AOF group once a day for 180 days.

Results: In the experiment on the alleviation of osteoporosis, the distribution of glucosaminoglycan in the bone matrix of the femoral bone was increased in the AOF group; moreover, the osteocalcin (OCN) positive reaction was increased and 8-OHdG positivity was decreased. In addition, AOF positively decreased RANKL, positively increased OPG, and positively decreased MMP-3. Muscle fiber loss in the endomysium following muscle degeneration of the quadriceps was reduced more in the $\mathrm{AOF}$ group compared with the $\mathrm{AE}$ group, and caspase-3 positive responses were also decreased. In addition, the 8-OHdG and $\mathrm{p}-\mathrm{lkB}$ positivity in the AOF group decreased compared with the $\mathrm{AE}$ group, and the Myo-D positivity increased.

Conclusion: We found that increasing bone formation alleviates osteoporosis, and that reducing bone loss alleviates muscle atrophy by reducing muscle loss and increasing muscle development
\end{abstract}

Key words: Alpiniae oxyphyllae fructus, osteoporosis, muscle dystrophy, OPG, RANKL, Myo-D

\section{I. 緒 論}

. 투고일: 2018.12.31, 심사일: 2019.03.30, 게재확정일: 2019.04.01

- Corresponding author: Sun-young Park Dept. of Physiology, College of Korean Medicine, Semyung University 65, Semyung-ro, Jecheon-si, Chungcheongbuk-do, Korea

TEL: +82-43-649-1345

E-mail: blbee@semyung.ac.kr

. 이 논문은 2018학년도 세명대학교 교내학술연구비 지원에 의해 수행된 연구임.
체내의 골은 결합조직의 한 형태이며, 골세포와 골양조직에서 생산된 세포외 유기기질로 구성되어 있다. 골은 생체기관을 보호하고 견고한 성질로 운 동을 가능하게 하며, 중력에 대한 부하를 지지한다. 또한 오래된 골은 지속적으로 흡수되고 새로운 골 을 형성하는데, 이를 통해 압력과 장력을 견딜 수 
있게 된다. 근육은 체중의 약 $40 \sim 50 \%$ 를 차지하는 인체에서 가장 큰 조직군으로 골격근은 남성체중 의 약 $40 \%$, 여성체중의 $32 \%$ 를 구성하고 있고, 평 활근과 심장근은 총 체중의 $10 \%$ 를 차지하고 있으 며, 운동, 호흡, 심장박동 등과 같은 필수적인 기능 을 담당하고 있다 ${ }^{1-5}$.

이처럼 우리 몸을 보호, 지탱하고 운동 및 생명 유지에 필요한 역할을 수행하고 있는 근골격계는 연령의 증가에 따라 골질량과 골밀도 및 근육량 감소가 나타난다. 골량은 실제 30 대 이후의 건강한 남성에서 척추 골량을 기준으로 매년 $2.3 \%$ 씩 감소 가 나타나며, 근육량은 50세 이상부터 해마다 1-2\% 씩 줄어들기 시작하여 80 세가 되면 최대 근육량의 약 절반정도로 그 양이 크게 감소하는 것으로 알 려져 있다 ${ }^{6-8}$.

골량의 감소와 미세구조의 이상을 특징으로 하 며 골이 약해져서 부러지기 쉬운 상태가 되는 전 신적인 골격계 질환이 골다공증이며 ${ }^{9}$, 나이가 들어 감에 따른 점진적인 근육량의 감소를 근육감소증 또는 근위축증이라고 한다 ${ }^{10}$. 즉, 골량의 감소가 지 속적으로 나타날 경우 경미한 충격에도 쉽게 골절을 일으킬 수 있고, 근육량의 감소로 근력과 신진대사 율, 최대 산소소모량의 감소가 발생할 수 있다 ${ }^{11-13}$.

현대사회는 세계적으로 평균수명이 연장되었고, 노인 비율이 급증함에 따라 노인의 기능저하와 만 성 퇴행성질환의 증가 등 노인문제가 우선적으로 해결되어야 할 사회적 문제로 대두되고 있다. 이에 노인의 삶의 질 향상과 노인질환에 쓰이는 사회 및 경제적 비용을 줄이기 위해 연령 증가로 나타 나는 골다공증이나 근위축 등의 근골격계 이상에 대한 예방 및 치료법 연구가 필요하다.

골다공증에 대한 한의학적 실험연구는 주로 난 소를 적출한 동물모델에 한약 추출물을 투여한 후 의 변화를 관찰하는 방법으로 진행되었으나 ${ }^{14-17}$ 이 는 모두 여성의 골다공증에만 국한되어 진행되고 있으며, 근위축의 경우 아직까지 진단기준이 모호 한 상태라 이에 대한 실증적인 연구가 부족한 실
정이다 ${ }^{18}$. 게다가 각 질환에 대한 개별적인 연구만 진행했을 뿐 연령 증가에 따른 근골격계 이상에 대한 복합적 연구는 현재까지 진행되지 않았다.

한의학적으로 골다공증은 骨瘘나 骨痺의 범주에 속하며, 腎陰虛나 腎陽虛가 주요 원인으로 滋陰强 骨하거나 溫補腎陽의 치료법을 사용한다 ${ }^{19}$. 근위축 은 한의학에서 外傷勞損, 濕熱侵襲, 肝腎虛勞 등의 원인으로 발생하는 瘘證에 해당하는 것으로 보며, 치료법으로는 活血化瘀, 清熱閏燥, 祛邪通絡, 盆氣 建脾, 滋陰補益肝腎 등이 있다 ${ }^{20}$. 또한 한의학에서 생장에 따른 신체 변화는 腎氣와 관련이 있으므로 ${ }^{21}$, 연령의 증가에 따른 골다공증 및 근위축 등 근골 격계 이상은 腎虛로 발생하는 것으로 생각되며, 補 腎의 약물을 통하여 증상을 개선시킬 수 있을 것 이라 추정된다.

监智仁은 생강과에 속하는 㿽智의 성숙한 果實로 서 溫脾胃하고 補腎하며 固精涉血하는 효능으로 腎 虛, 奪精, 膀胱虛寒, 小便不禁, 下血 등의 증상에 사용 되었다 ${ }^{22}$. 益智仁에 대한 연구로 신장기능 개선효과 ${ }^{23}$, 음경해면체 평활근 이완효과 ${ }^{24}$, 골 손실 및 파골세포 분화 억제효과 ${ }^{25}$ 등이 있으며, 이들 연구의 대부분은 益智仁의 補腎효과에 중점을 두고 진행되었다.

이에 저자는 㞷智仁이 노화로 인한 근골격계 이 상에 개선효과가 있을 것이라 생각하였고, 대표적 인 근골격계 이상인 골다공증과 근위축 증상을 중 심으로 조직화학 및 면역조직화학적 방법을 이용 하여 실험을 진행하였다.

\section{II. 材料 吕 方法}

\section{1. 실험동물}

평균 몸무게 $32 \pm 5 \mathrm{~g}$ 의 8 주령의 ICR계 수컷 생 쥐(샘타코, 한국)와 평균 몸무게 $60 \pm 8 \mathrm{~g}$ 의 50 주령 $\mathrm{ICR}$ 계 수컷 생쥐(중앙실험동물, 한국)를 사용하였 으며 모든 동물은 고형사료와 물을 충분히 공급하면 서 1 주 이상 일정한 온도 $\left(25 \pm 2{ }^{\circ} \mathrm{C}\right)$ 와 습도 $(50 \pm 5 \%)$ 가 유지되는 실험실 환경에 적응시킨 후 사용하였다. 
본 동물실험은 세명대학교 동물실험윤리위원회 의 승인(smecac 18-12-04)하에 실시되었다.

\section{2. 监智仁 추출물 제조}

盆智仁(Alpiniae Oxyphyllae Fructus, AOF)은 세명대학교 부속 제천한방병원에서 구입하여 사용 하였다. 益智仁 $300 \mathrm{~g}$ 을 round flask에 넣고 증류수 $3000 \mathrm{ml}$ 을 첨가한 후 $100{ }^{\circ} \mathrm{C}$ 에서 2 시간 동안 가열 추출하였다. 추출한 다음 rotary evaporator(Eyela, Japan)로 감압 농축하였고, 농축액은 동결건조기 로 건조하여 분말 $17.09 \mathrm{~g}(17.6 \%)$ 을 제조하여 실험 에 사용하였다.

\section{3. 실험군의 설정 및 益智仁 추출물의 투여}

실험군은 총 27 마리로, 각각 9 마리씩 정상군 (control group)과 노화군(aging-elicited group, $\mathrm{AE}$ group), 监智仁 추출물군(Alpiniae Oxyphyllae Fructus group, AOF group)으로 분류하였으며, 정상군은 아무런 처치를 하지 않은 8 주령의 ICR계 생쥐를 사용하였고, 노화군과 益智仁 추출물군은 50 주령의 ICR계 생쥐를 사용하였다. 노화군은 별다른 처치 없이 증류수 $10 \mathrm{ml}$ 를 180 일 동안 투여하였고, 盆智 仁 추출물군은 益智仁 추출물 $(0.54 \mathrm{~g} / \mathrm{kg})$ 을 증류수 $10 \mathrm{ml}$ 에 녹여 1일 1회씩 180일 동안 투여하였다.

\section{4. 골다공증 개선효과 측정}

\section{1) 조직 표본 제작}

180일의 실험을 마친 후 181일째 흰쥐를 ether로 마취하여 대퇴골을 적출한 후 대퇴골 주위의 지방 및 근육들을 제거하고 실온에서 24시간 동안 $10 \%$ neutral buffered formalin(NBF)에 고정하였으며, 고정된 대퇴골은 탈회액(decalcification solution, $\mathrm{BBC}, \mathrm{UK}$ )에 12 시간 처리하고 세척한 후 통상적 인 방법으로 파라핀에 포매하여 $5 \mu \mathrm{m}$ 두께로 연속 절편을 만들었다.

2) 뼈조직내 미세환경 관찰을 위한 조직화학 대퇴골 내 glucosaminoglycan(GAG)의 분포변화
를 조사하기 위해 Safranin-O-fast green $(\mathrm{S} / \mathrm{F})$ 염색 을 실시한 후 광학현미경(BX51. Olympus, Japan) 으로 관찰하였다.

3) 뼈조직내 미세환경 관찰을 위한 면역조직화학 골내 칼슘침적에 관여하는 osteocalcin $(\mathrm{OCN})$ 과 산 화스트레스에 의한 유전자손상에 관여하는 ${ }^{8} \mathrm{-OHdG}$ 의 분포변화를 조사하기 위해 mouse anti OCN와 mouse anti $8-0 \mathrm{HdG}$ 를 이용한 면역조직화학적 염 색을 실시하였다. 우선 뼈조직절편을 proteinase $\mathrm{K}$ $(20 \mu \mathrm{g} / \mathrm{ml})$ 에 5 분 동안 proteolysis 과정을 거친 후 blocking serum인 10\% normal goat serum에서 2시 간 동안 반응시켰다. 그리고 1차 항체인 mouse anti OCN(1:50, Santa Cruz Biotec, USA)과 mouse anti 8-OHdG(1:100, Santa Cruz Biotec, USA)에 $4{ }^{\circ} \mathrm{C}$ humidified chamber에서 72시간 동안 반응시켰다. 그런 다음 2차 항체인 biotinylated goat anti-mouse $\operatorname{IgG1}(1: 100, \mathrm{DAKO}, \mathrm{USA})$ 에 실온에서 24시간 link 하였고, 그런 다음 avidin biotin complex kit(Vector $\mathrm{Lab}, \mathrm{USA}$ )에 1시간 동안 실온에서 반응시켰다. $0.05 \% 3,3$-diaminobenzidine과 $0.01 \% \mathrm{HCl}$ 이 포함 된 $0.05 \mathrm{M}$ tris $-\mathrm{HCl}$ 완충용액 $(\mathrm{pH} 7.4)$ 에서 발색시 킨 후, hematoxylin으로 대조염색하였다.

4) 골다공증 발병 조절 관찰을 위한 면역조직화학

골다공증 발병기전에 관여하는 Reaction of activation of nuclear factor kappa B ligand(RANKL, 1:50, Santa Cruz Biotec, USA)와 osteoprotegerin(OPG, 1:50, Santa Cruz Biotec, USA) 그리고 골성조직의 분해에 관여하는 MMP-3(1:50, Santa Cruz Biotec, $\mathrm{USA})$ 의 변화를 관찰하기 위해 면역조직화학적 염 색을 실시하였다.

\section{5. 근위축 개선효과 측정}

1) 조직 표본 제작

흰쥐를 ether로 마취하여 대퇴사두근을 적출한 후 주위의 지방조직들을 제거하고 실온에서 24시 간 동안 $10 \% \mathrm{NBF}$ 에 고정하였으며, 고정된 조직은 통상적인 방법으로 paraffin에 포매한 후 $5 \mu \mathrm{m}$ 두 
께의 연속절편으로 제작되었다.

2) 근육퇴화 조절효과 관찰을 위한 조직화학

대퇴사두근의 근육퇴화에 따른 근육속막(endomysium) 내 근유섬유의 변화를 보기 위해 Phloxine-tartrazine 염색법을 실시한 후 광학현미경(BX51. Olympus, Japan)으로 관찰하였다.

3) 근육퇴화 조절효과 관찰을 위한 면역조직화학 산화스트레스에 의한 유전자손상에 관여하는 $8-0 \mathrm{HdG}$ 변화를 관찰하기 위해 면역조직화학적 염 색을 실시하였다. 우선 근육절편을 proteinase $\mathrm{K}$ $(20 \mu \mathrm{g} / \mathrm{ml})$ 에 5 분 동안 proteolysis 과정을 거친 후 blocking serum인 10\% normal goat serum에서 2시 간 동안 반응시켰다. 그리고 1차 항체인 mouse anti 8-OHdG(1:100, Santa Cruz Biotec, USA)에 $4{ }^{\circ} \mathrm{C}$ humidified chamber에서 72시간 동안 반응시켰다. 그런 다음 2차 항체인 biotinylated goat anti-mouse $\operatorname{IgG2a}(1: 100, \mathrm{DAK} 0, \mathrm{USA})$ 에 실온에서 24시간 link 하였고, 그런 다음 avidin biotin complex kit(Vector $\mathrm{Lab}, \mathrm{USA}$ )에 1 시간 동안 실온에서 반응시켰다. $0.05 \%$ 3,3'-diaminobenzidine과 $0.01 \% \mathrm{HCl}$ 이 포함된 $0.05 \mathrm{M}$ tris- $\mathrm{HCl}$ 완충용액(pH 7.4)에서 발색시킨 후, hematoxylin 으로 대조염색하였다.

4) 근육재생 조절효과 관찰을 위한 면역조직화학 근육재생조절 효과를 관찰하기 위해 근막내 염 증에 관여하는 $\mathrm{p}-\mathrm{IkB}(1: 250$, Santa Cruz Biotec, USA), 근육내 세포자멸사에 관여하는 caspase-3 (1:100, Santa Cruz Biotec, USA) 그리고 근육재생 에 관여하는 Myo-D (1:50, Santa Cruz Biotec, USA) 등의 변화를 관찰하기 위해서 면역조직화학적 염 색을 실시하였다.

\section{6. 영상분석과 통계처리}

면역조직화학 결과를 조사하기 위해 Image pro Plus(Media Cybernetic, USA)을 이용한 영상분석 (image analysis)을 실시하여 수치화(means \pm standard error) 했다. 각 군의 표본에서 임의로 선정된 지역을 x200배율에서 촬영한 다음 positive pixels/20,000,000 pixels로 영상분석 하였다. 통계는 SPSS software(SPSS 23, SPSS Inc., USA)를 사용하였으며, one-way ANOVA 시행을 통해 유의성 $(\mathrm{P}<0.05)$ 을 검증하고 Duncan's multiple range test로 사후 검증하였다.

\section{III. 結 果}

\section{1. 㿽智仁이 골다공증에 미치는 영향}

1) 뼈조직내 미세환경에 미치는 영향

대퇴골의 치밀뼈내 뼈기질에서 glucosaminoglycan $(\mathrm{GAG})$ 분포 변화를 관찰한 결과, control군의 대 퇴골보다 $\mathrm{AE}$ 군의 대퇴골에서 분포가 감소하였으 며, $\mathrm{AOF}$ 군에서는 $\mathrm{AE}$ 군에 비해 치밀뼈내 뼈기질 유실지역에서 $\mathrm{GAG}$ 의 분포가 증가하였다.

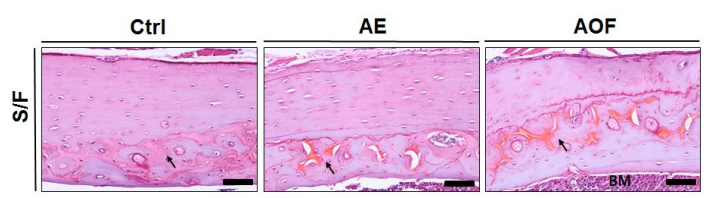

Fig. 1. Changes in glucosaminoglycan (GAG) distribution in the bone matrix of the femur.

S/F : Safranin-0-fast green stain, Ctrl : control group, AE : aging-elicited group, AOF : Alpiniae Oxyphyllae Fructus group, BM : bone marrow, Arrow : positive reaction, Bar size : $50 \mu \mathrm{m}$

2) 뼈조직내 칼슘침적에 미치는 영향

뼈내 칼슘침적에 관여하는 osteocalcin $(\mathrm{OCN})$ 의 분포변화를 관찰한 결과, 노화된 $\mathrm{AE}$ 군 생쥐의 대 퇴골에서 $\mathrm{OCN}$ 양성반응은 감소하였지만, $\mathrm{AOF}$ 군 에서는 $\mathrm{AE}$ 군에 비해 $104 \%$ 증가하였다.

Table 1. OPC Positive Reaction Change in the Femur of Mouse

\begin{tabular}{cccc}
\multirow{2}{*}{ Objective } & \multicolumn{3}{c}{ Group } \\
\cline { 2 - 4 } & Control & AE & AOF \\
\hline \multirow{2}{*}{ OPC } & 76,690 & 22,733 & 46,477 \\
& $\pm 1,483$ & \pm 885 & $\pm 1,121^{* * *}$ \\
\hline
\end{tabular}

Values are mean \pm deviation $(\mathrm{n}=10)$. Image analysis for 20,000,000 pixel cells. ${ }^{* * *} p\langle 0.001$ compared with AE. 


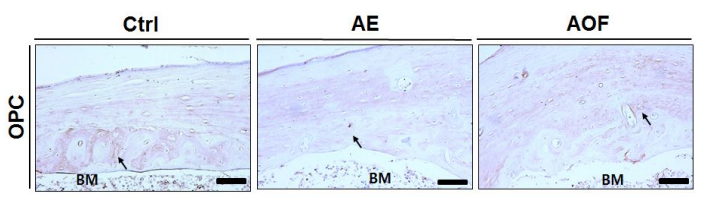

Fig. 2. Changes in the distribution of osteocalcin (OPC) in the femur.

OPC : osteocalcin immunohistochemistry, Ctrl : control group, $\mathrm{AE}$ : aging-elicited group, $\mathrm{AOF}$ : Alpiniae Oxyphyllae Fructus group, BM : bone marrow, Arrow : positive reaction, Bar size : $50 \mu \mathrm{m}$

3) 뼈조직내 산화스트레스에 미치는 영향

산화스트레스에 의한 유전자손상에 관여하는 $8-0 \mathrm{HdG}$ 의 분포변화를 관찰한 결과, 노화된 $\mathrm{AE}$ 군 생쥐의 대퇴골 조직 내에서 $8-0 \mathrm{HdG}$ 양성반응은 증가하였지만, $\mathrm{AOF}$ 군에서는 $\mathrm{AE}$ 군에 비해 $49 \%$ 감 소하였다.

Table 2. 8-OHdG Positive Reaction Change in the Femur of Mouse

\begin{tabular}{cccc}
\hline \multirow{2}{*}{ Objective } & \multicolumn{3}{c}{ Group } \\
\cline { 2 - 4 } & Control & AE & AOF \\
\hline \multirow{2}{*}{ 8-OHdG } & 9,798 & 70,134 & 35,712 \\
& \pm 338 & \pm 830 & $\pm 1,104^{* * *}$ \\
\hline
\end{tabular}

Values are mean \pm deviation $(\mathrm{n}=10)$. Image analysis for 20,000,000 pixel cells. ${ }^{* * *} p\langle 0.001$ compared with AE.

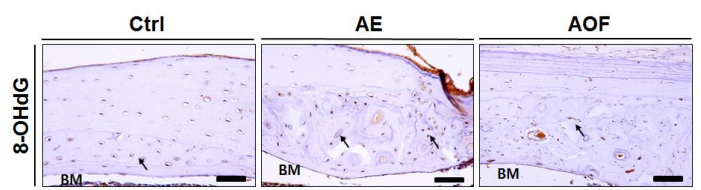

Fig. 3. Distribution of $8-\mathrm{OHdG}$ in the femur.

8-OHdG, 8-OHdG immunohistochemistry, Ctrl : control group, AE : aging-elicited group, AOF : Alpiniae Oxyphyllae Fructus group, BM : bone marrow, Arrow : positive reaction, Bar size : $50 \mu \mathrm{m}$

4) 골다공증 발병기전에 미치는 영향

골다공증 발병기전에 관여하는 RANKL과 $\mathrm{OPG}$, 골성조직의 분해에 관여하는 $\mathrm{MMP}-3$ 의 변화를 관
찰하였다.

노화된 $\mathrm{AE}$ 군 생쥐의 RANKL 양성반응은 control 군에 비해 증가하였지만, $\mathrm{AOF}$ 군에서는 $\mathrm{AE}$ 군에 비 해 $60 \%$ 감소하였으며, $\mathrm{OPG}$ 양성반응은 control군에 비해 $\mathrm{AE}$ 군에서 감소하였지만, $\mathrm{AOF}$ 군에서는 $\mathrm{AE}$ 군 에 비하여 $113 \%$ 증가하였다. 또한 MMP-3 양성반 응은 노화된 $\mathrm{AE}$ 군에서는 증가하였지만, $\mathrm{AOF}$ 군에서 는 $\mathrm{AE}$ 군에 비해 $36 \%$ 감소하였다.

Table 3. RANKL, OPG, MMP-3 Positive Reaction Change in the Femur of Mouse

\begin{tabular}{cccc}
\hline \multirow{2}{*}{ Objective } & \multicolumn{3}{c}{ Group } \\
\cline { 2 - 4 } & Control & AE & AOF \\
\hline \multirow{2}{*}{ RANKL } & 9,623 & 71,334 & 35,789 \\
& \pm 586 & \pm 974 & $\pm 1,033^{* *}$ \\
\multirow{2}{*}{ OPG } & 62,399 & 14,744 & 31,429 \\
& $\pm 1,072$ & \pm 807 & $\pm 1,118^{* * *}$ \\
\multirow{2}{*}{ MMP-3 } & 5,233 & 66,051 & 42,305 \\
& \pm 404 & $\pm 1,305$ & $\pm 1,299 * * *$ \\
\hline
\end{tabular}

Values are mean \pm deviation $(\mathrm{n}=10)$. Image analysis for $20,000,000$ pixel cells. ${ }^{* * *} p<0.001$ compared with AE.

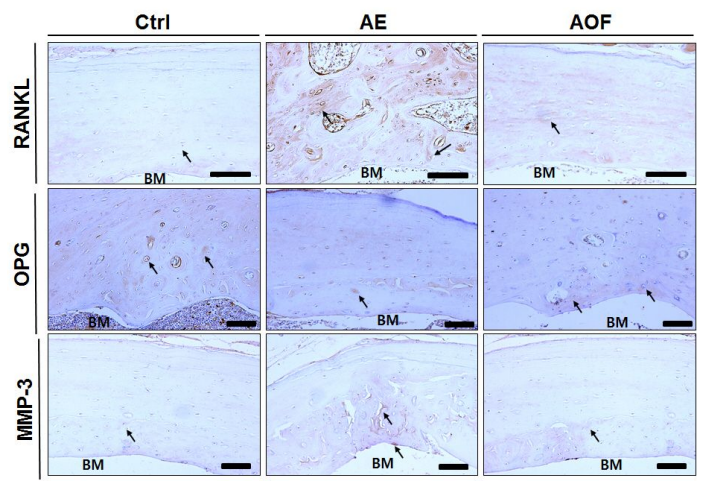

Fig. 4. Changes in RANKL, OPG, and MMP-3 in the femur.

RANKL : RANKL immunohistochemistry, OPG : OPG immunohistochemistry, MMP-3 : MMP-3 immunohistochemistry, Ctrl : control group, AE : aging-elicited group, AOF : Alpiniae Oxyphyllae Fructus group, BM : bone marrow, Arrow : positive reaction, Bar size : $50 \mu \mathrm{m}$ 


\section{2. 賹智仁이 근위축에 미치는 영향}

1) 근육속막내 근육섬유에 미치는 영향

대퇴사두근의 근육퇴화에 따른 근육속막(endomysium) 내 근육섬유의 변화를 관찰한 결과, 노화된 $\mathrm{AE}$ 군 생쥐에서 근육속막내 근육섬유의 소실이 관찰되었 다. 하지만 $\mathrm{AOF}$ 군에서는 $\mathrm{AE}$ 군에 비해 근육속막내 근육섬유의 소실이 감소하였다.

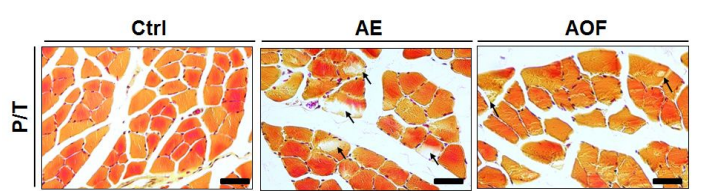

Fig. 5. Muscle fiber changes in endomysium by muscle degeneration.

P/T : Phloxine-tartrazine stain, Ctrl : control group, AE : aging-elicited group, AOF : Alpiniae Oxyphyllae Fructus group, Arrow : positive reaction, Bar size : $50 \mu \mathrm{m}$

2) 근육내 산화스트레스에 미치는 영향

산화스트레스에 의한 유전자손상에 관여하는 $8-\mathrm{OHdG}$ 변화를 관찰한 결과, 노화된 $\mathrm{AE}$ 군 생쥐 의 근육내 $8-0 \mathrm{HdG}$ 양성반응은 증가하였다. 하지 만 $\mathrm{AOF}$ 군에서는 $\mathrm{AE}$ 군에 비해 근육내 $8 \mathrm{OHdG}$ 양 성반응이 $53 \%$ 감소하였다.

Table 4. 8-OHdG Positive Reaction Change in the Quadriceps Muscle

\begin{tabular}{cccc}
\multirow{2}{*}{ Objective } & \multicolumn{3}{c}{ Group } \\
\cline { 2 - 4 } & Control & AE & AOF \\
\hline \multirow{2}{*}{ 8-OHdG } & 3,881 & 53,200 & 24,781 \\
& \pm 273 & $\pm 1,764$ & $\pm 953 * * *$ \\
\hline
\end{tabular}

Values are mean \pm deviation $(\mathrm{n}=10)$. Image analysis for 20,000,000 pixel cells. ${ }^{* * *} p\langle 0.001$ compared with AE.

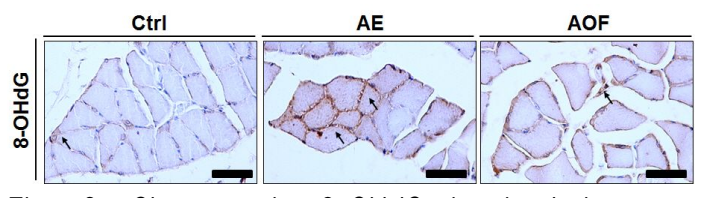

Fig. 6. Changes in 8-OHdG involved in gene damage caused by oxidative stress.

8-OHdG : 8-OHdG immunohistochemistry, Ctrl : control group, $\mathrm{AE}$ : aging-elicited group, $\mathrm{AOF}$ : Alpiniae Oxyphyllae Fructus group, Arrow : positive reaction, Bar size : $50 \mu \mathrm{m}$

3) 근막 내 염증에 미치는 영향

근막 내 염증에 관여하는 $\mathrm{p}-\mathrm{IkB}$ 변화를 관찰한 결과, 노화된 $\mathrm{AE}$ 군 생쥐의 근막 내에서 $\mathrm{p}-\mathrm{IkB}$ 양 성반응은 증가하였다. 하지만 $\mathrm{AOF}$ 군의 $\mathrm{p}-\mathrm{IkB}$ 양 성반응은 $\mathrm{AE}$ 군에 비해 $50 \%$ 감소하였다.

Table 5. $\mathrm{p}$-IkB Positive Reaction Change in the Quadriceps Muscle

\begin{tabular}{cccc}
\multirow{2}{*}{ Objective } & \multicolumn{3}{c}{ Group } \\
\cline { 2 - 4 } & Control & AE & AOF \\
\hline \multirow{2}{*}{ p-IkB } & 3,755 & 30,820 & 15,291 \\
& \pm 354 & $\pm 1,322$ & $\pm 1,097 * * *$ \\
\hline
\end{tabular}

Values are mean \pm deviation $(\mathrm{n}=10)$. Image analysis for 20,000,000 pixel cells. ${ }^{* * *} p\langle 0.001$ compared with AE.

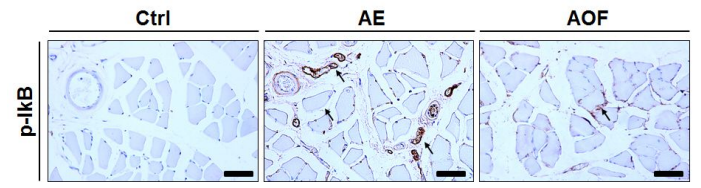

Fig. 7. Changes in $\mathrm{p}-\mathrm{IkB}_{\mathrm{k}}$ involved in intrafascial inflammation.

p-lkB : p-lkB immunohistochemistry, Ctrl : control group, AE : aging-elicited group, AOF : Alpiniae Oxyphyllae Fructus group, Arrow : positive reaction, Bar size : $50 \mu \mathrm{m}$

4) 근육 내 세포자멸사에 미치는 영향

근육 내 세포자멸사에 관여하는 caspase-3 변화 를 관찰한 결과, 노화된 $\mathrm{AE}$ 군 생쥐의 근육내에서 caspase-3 양성반응은 증가하였다. 하지만 $\mathrm{AOF}$ 군 
에서는 $\mathrm{AE}$ 군에 비해 $54 \%$ 의 caspase-3 양성반응 감소가 관찰되었다.

Table 6. Myo-D Positive Reaction Change in the Quadriceps Muscle

\begin{tabular}{cccc}
\hline \multirow{2}{*}{ Objective } & \multicolumn{3}{c}{ Group } \\
\cline { 2 - 4 } & Control & AE & AOF \\
\hline \multirow{2}{*}{ Caspase-3 } & 3,760 & 56,176 & 25,863 \\
& \pm 369 & $\pm 1,633$ & $\pm 1,073 * * *$ \\
\hline
\end{tabular}

Values are mean \pm deviation $(\mathrm{n}=10)$. Image analysis for 20,000,000 pixel cells. ${ }^{* * *} p\langle 0.001$ compared with AE.

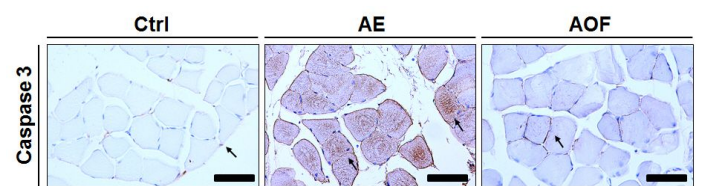

Fig. 8. Changes in caspase-3 involved in intramuscular apoptosis.

Caspase-3 : Caspase-3 immunohistochemistry, Ctrl : control group, AE : aging-elicited group, AOF : Alpiniae Oxyphyllae Fructus group, Arrow : positive reaction, Bar size : $50 \mu \mathrm{m}$

5) 근육재생에 미치는 영향

근육재생에 관여하는 $\mathrm{Myo}-\mathrm{D}$ 변화를 관찰한 결과, 노화된 $\mathrm{AE}$ 군 생쥐의 $\mathrm{Myo}-\mathrm{D}$ 양성반응은 control군 에 비해 감소하였다. 하지만 $\mathrm{AOF}$ 군에서는 $\mathrm{Myo}-\mathrm{D}$ 양성반응이 $\mathrm{AE}$ 군에 비해 $147 \%$ 증가하였다.

Table 7. Myo-D Positive Reaction Change in the Quadriceps Muscle

\begin{tabular}{cccc}
\multirow{2}{*}{ Objective } & \multicolumn{3}{c}{ Group } \\
\cline { 2 - 4 } & Control & AE & AOF \\
\hline \multirow{2}{*}{ Myo-D } & 62,003 & 10,838 & 26,749 \\
& $\pm 1,402$ & \pm 501 & $\pm 871^{* * *}$ \\
\hline
\end{tabular}

Values are mean \pm deviation $(\mathrm{n}=10)$. Image analysis for 20,000,000 pixel cells. ${ }^{* * *} p\langle 0.001$ compared with AE.

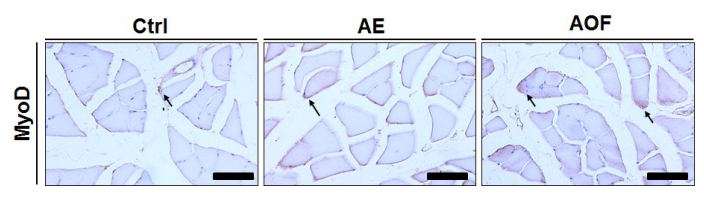

Fig. 9. Changes in Myo-D involved in muscle regeneration.

Myo-D : Myo-D immunohistochemistry, Ctrl : control group, $\mathrm{AE}$ : aging-elicited group, $\mathrm{AOF}$ : Alpiniae Oxyphyllae Fructus group, Arrow : positive reaction, Bar size : $50 \mu \mathrm{m}$

\section{IV. 考察}

골은 주로 $\mathrm{Ca}^{2+}$ 으로 구성된 세포외 유기기질 또 는 osteoid로 구성되어 있는 살아있는 조직으로, 침 착과 흡수가 정상적으로 동시에 일어나 항상 재형 성이 이루어지고 있다. 골 속에는 조골세포, 파골 세포 등 두 가지 유형의 골세포가 존재하는데, 조 골세포는 칼슘결정이 침착하게 되는 세포외 유기 기질을 분비하고, 파골세포는 근처의 골을 흡수하 는 세포로 칼슘결정을 녹이는 산과 유기 기질을 분해하는 효소를 분비한다. 이렇듯 조골세포가 파 골세포와 대응하는 일정한 세포성 줄다리기가 계 속 발생하면서 골은 재형성되며, 이를 통해 골의 형성과 흡수속도는 거의 동일하게 일어나서 전체 골량은 일정하게 유지된다. 하지만 이러한 균형에 변화가 생겨 골의 형성보다 흡수가 더 많을 경우 전체 골량은 감소하게 되며 경미한 충격에도 쉽게 골절이 발생할 수 있는 골다공증이 발생하게 된다.

근육은 근육세포들의 결합조직으로, 수축운동을 통하여 개체의 이동, 자세유지 및 체액분비 등을 담당하는 신체기관이다. 근육은 일반적으로 체성 근육조직으로 이루어져있는 골격근과 심장에 위치 하는 심장근, 내장에서 발견되는 평활근의 세 형태 로 분류된다. 남자 체중의 $40 \%$, 여자 체중의 $32 \%$ 를 차지하는 골격근의 경우 근육계의 기본구조인 근섬유로 구성되어 있으며, 근섬유는 또한 다양한 근섬유 단백질로 구성되어 있다. 하나의 근육은 수 
천 개의 근섬유로 구성되어 있고, 근섬유를 둘러싸 고 있는 세포막인 근육속막(근초)은 화학적, 전기 적 자극에 의해 흥분되며 신호를 전달하는 특성이 있다. 이러한 근육은 건에 의해 양 끝이 골에 연결 되어 있으며, 이를 통해 수축, 이완의 작용을 하게 된다 ${ }^{1-2}$. 하지만 근섬유 단백질의 분해가 증가될 경 우 전체 근육량의 감소가 나타나는데, 점진적인 근 육량 감소의 가장 큰 원인은 노화에 의한 근육량 의 감소이며 이로 인해 근위축 증상이 발생한다 ${ }^{26}$.

연령 증가에 의한 노화로 장기무게의 감소, 자율 신경계 활동 저하, 호르몬 분비 저하, 연령 증가에 따른 점진적인 근육량 감소, 골질량 및 골격근의 감소 등이 일어난다 ${ }^{27}$. 보통 인체의 활동에 관여하 는 골과 근육을 합하여 근골격계라고 부르는데, 연 령이 증가함에 따라 골다공증 및 근위축 등의 근 골격계 이상이 발생하고, 이로 인해 신체 기능의 저하, 활동 감소, 낙상 및 골절, 보행장애, 쇠약 외 에 대사 관련 질환도 발생할 수 있으므로 ${ }^{7,828}$ 이에 대한 대비책의 일환으로 노화에 따른 근골격계 이 상에 대해 특별한 관심이 필요하다.

현재 사용되고 있는 골다공증 치료법은 경구용 약물로 크게 골흡수 억제제와 골형성 촉진제로 구 분되지만 대부분 골흡수 억제제의 영역에 속한다. 하지만 이 약물들은 속쓰림, 구역질, 궤양 등의 소 화기 자극 증상이나, 안면홍조, 관상동맥질환의 위 험도 증가, 유방암, 뇌졸중 등의 유발가능성이 높 다는 부작용이 있다 ${ }^{29.30}$. 또한 근위축에 대한 치료 법으로 저항 훈련 등이 효과가 있다고 알려져 있 지만 ${ }^{31}$ 훈련법에 대한 자세한 설명 및 기준이 제시 되어 있지는 않으며, 현재까지 권장되는 치료제는 없다. 따라서 기존 치료제의 부족한 점 및 부작용 을 보완하면서 골다공증과 근위축 등에 모두 효과 를 나타낼 수 있는 치료제의 개발이 요구된다.

한의학에서는 사람의 수명이 腎氣가 연관이 있 다고 하여 연령이 증가함에 따라 腎氣가 소모된다 고 하였고 ${ }^{21}$, 腎主骨이라 하여 骨과 腎이 밀접한 관 계를 가지고 있으므로 노화에 따른 골다공증은 腎
虛가 주요 원인이 되는 骨瘘, 骨痺와 부합한다고 하였다 ${ }^{19}$. 또한 근위축은 筋骨瘘軟이 主가 되는 瘘 證의 범주에 속한다고 하였으며, 이에 대한 治法으 로 滋院淸火, 淸肺潤燥, 補益脾胃, 調補肝腎 등이 중시되었다 ${ }^{20}$. 즉, 연령의 증가에 따른 근골격계 이 상인 골다공증과 근위축은 모두 腎氣의 不足이 원 인이 될 수 있으며, 補腎하는 약물을 응용하여 치 료할 수 있을 것이라 생각된다.

盆智仁은 性味는 辛溫하고 補腎溫脾의 효능으로 예로부터 신장질환 및 배뇨조절에 효능이 있는 약 재로 알려져 왔다 ${ }^{22}$. 益智仁에 대한 연구로 이 등 ${ }^{23}$ 은 益智仁이 허혈-재관류로 인한 급성 신부전 백서 에서 허혈성 급성신부전으로 인해 발생하는 증상들 을 회복시켜 신장기능의 장애를 개선시킨다고 보고 하였고, 박 등 ${ }^{24}$ 은 益智仁 추출물이 prostacyclin과, $\mathrm{eNOS}$ 를 통한 $\mathrm{NO}$ 의 생성 증가로 평활근에서의 cGMP 농도를 증가시키고, 세포외 $\mathrm{Ca}^{2+}$ 의 유입을 차단하는 경로를 통하여 음경해면체 이완효과를 나타낸다고 하였으며, 하 등 ${ }^{25}$ 은 盆智仁 물 추출물 이 RANKL로 유도된 파골세포 분화를 억제함으로 써 골 소실에 대해 보호효과를 드러낸다고 보고하 였다. 이렇듯 益智仁에 대한 많은 연구가 補腎작용 에 중점을 두고 진행되어 왔지만 노화에 따른 근 골격계 변화에 복합적으로 미치는 영향에 관한 연 구는 없다.

이에 저자는 縊智仁이 補腎작용이 노화로 인한 근골격계 이상에 개선효과가 있을 것이라 생각하 여 대표적인 근골격계 이상인 골다공증과 근위축 을 중심으로 연구를 진행하였다.

益智仁이 골다공증에 미치는 영향에 대한 연구에 서 대퇴골의 치밀뼈내 뼈기질에서 glucosaminoglycan $(\mathrm{GAG})$ 분포는 $\mathrm{AE}$ 군에 비하여 $\mathrm{AOF}$ 군에서 증가하 였다. GAG는 반복성 이당류의 기본구조를 갖는 선상 구조의 다당류로, 외부로부터의 압력에 기계 적으로 저항하는 힘을 세포외기질에 부여하며 콜 라겐 합성뿐만 아니라 섬유모세포의 증식에도 영 향을 준다 ${ }^{32-34}$. 따라서 $\mathrm{GAG}$ 의 분포가 益智仁으로 
인해 증가되었다는 결과를 통해 䝷智仁이 노화로 인해 발생한 뼈기질의 손상을 감소시킴으로써 골 다공증을 개선시킨다는 사실을 알 수 있다.

Osteocalcin은 골형성에 중요한 기질단백 중 하 나로, 세포외 비교원성 유기물질 중 10-20\%를 차 지하며, 골절 치유 및 골형성 과정의 빼모세포와 유골기질에서 강하게 발현되고 골형성 과정이 진 행되면서 점차 소실된다 ${ }^{35}$. 따라서 $\mathrm{OCN}$ 양성반응 이 $\mathrm{AE}$ 군에 비해 $\mathrm{AOF}$ 군에서 증가되었다는 것은 益智仁의 골다공증 개선효과가 뼈모세포의 활성 증가를 통한 골 형성을 통해 일어난다는 사실을 알려준다.

그리고 산화스트레스에 의한 유전자손상에 관여 하는 $8-0 \mathrm{HdG}$ 의 분포는 $\mathrm{AE}$ 군에 비해 $\mathrm{AOF}$ 군에서 감소하였다. 산화스트레스는 세포내 DNA를 손상 시켜 신경세포를 사망하게 하고 노화를 유발할 수 있다 ${ }^{36}$. 즉, $8-0 \mathrm{HdG}$ 양성반응이 盆智仁에 의하여 감소하였으므로 㿽智仁이 골 내 산화스트레스의 감소에 관여하여 골다공증 개선효과를 나타내는 것으로 생각된다.

RANKL은 RANK이라는 수용체와 결합하여 대 식세포에서 파골세포로 분화를 촉진하고 파골세포 의 세포자멸사를 억제함으로써 파골세포의 작용을 증가시키며, $\mathrm{MMP}-3$ 은 관절의 연골조직 구성성분 을 분해하는 효소이다 ${ }^{37.38}$. 반면 OPG는 RANKL과 결합하여 RANK의 작용을 차단함으로써 파골세포 의 작용은 억제시키고 조골세포의 작용을 촉진시 킨다2. RANKL과 MMP-3 양성반응이 감소되고 $\mathrm{OPG}$ 양성반응이 증가된 결과는 盆智仁이 빼 흡수 와 연골조직의 구성성분 분해를 억제하면서 조골 세포에 의한 뼈 형성을 촉진하여 골다공증 개선효 과를 나타내는 것으로 생각된다.

다음으로 盈智仁이 근위축에 미치는 영향에 대 한 연구에서 대퇴사두근의 근육퇴화에 따른 근육 속막(endomysium)내 근섬유의 변화를 관찰한 결 과, 노화된 $\mathrm{AE}$ 군 생쥐에서 관찰된 근섬유의 소실 이 $\mathrm{AOF}$ 군에서는 감소하였고, caspase-3 양성반응
도 盈智仁 투여로 감소하였다. Caspase는 세포의 $\mathrm{DNA}$ 복제 및 유전자 발현과 관련된 단백질과, 핵 의 구조유지, 세포의 항상성 유지 등과 관련된 단 백질들을 파괴시키거나 관련된 단백질의 활성 증 가로 세포사멸을 유도하는 물질이다 ${ }^{39}$. 즉, 亚智仁 은 근육내 세포자멸사를 감소시켜 근섬유의 소실 을 억제함으로써 근위축을 개선하는 것으로 생각 된다.

또한 근육내 산화스트레스에 의한 유전자손상에 관여하는 $8-\mathrm{OHdG}$ 양성반응은 $\mathrm{AE}$ 군에 비하여 $\mathrm{AOF}$ 군에서 감소하였고, 근막내 염증 발생 시 분비 되는 $\mathrm{p}-\mathrm{IkB}$ 양성반응도 $\mathrm{AE}$ 군에 비하여 $\mathrm{AOF}$ 군에 서 비해 감소하였다. 이로써 益智仁의 근위축 개선 효과는 산화스트레스 및 근막내 염증을 감소시킴 으로써 나타난다는 사실을 알 수 있다.

Myo-D는 근육세포의 핵과 satellite cell에서 발 현되는 근세포생성과정의 중요한 조절인자의 일종 으로 근세포가 아닌 세포를 근세포로 전환시키는 능력이 있으며, 근세포 분화에도 관여한다 ${ }^{40}$. 따라 서 노화된 $\mathrm{AE}$ 군 생쥐에서 감소된 $\mathrm{Myo}-\mathrm{D}$ 양성반 응이 $\mathrm{AOF}$ 군에서 증가한 결과는 监智仁이 근세포 수를 증가시켜 근육생성에 관여함으로써 근위축을 개선한다는 사실을 나타낸다.

위의 결과를 종합하면, 益智仁은 뼈모세포의 활 성 증가 및 파골세포 작용 억제, 골내 산화스트레 스 감소와 연골조직의 구성성분 분해를 억제하여 빼기질의 손상을 감소시킴으로써 골다공증을 개선 하는 것으로 생각된다. 또한 益智仁은 근육내 세포 자멸사를 감소시켜 근섬유의 소실을 억제하고 근 세포수를 증가시켜 근육생성에 관여하며, 산화스트 레스 및 근막내 염증을 감소시킴으로써 근위축을 개선하는 것으로 생각된다. 이상의 결과를 통해 ㅅㅛㅛ 智仁은 노화로 인한 근골격계 이상인 골다공증과 근위축을 모두 개선시키는 효과가 있다는 사실을 알 수 있으며, 이를 바탕으로 노화로 인한 골다공 증과 근위축을 모두 개선하는 약물로 활용할 수 있을 것이라 생각된다. 


\section{V. 結 論}

補腎의 작용이 뛰어난 益智仁이 노화로 인한 근 골격계 이상의 개선에 미치는 영향을 검증하기 위 하여 대표적인 근골격계 이상인 골다공증과 근위 축을 중심으로 실험을 진행하여 다음과 같은 결과 를 얻었다.

먼저 盆智仁이 골다공증의 개선에 미치는 영향 에 대한 실험을 진행한 결과, 대퇴골의 치밀뼈 내 뼈기질에서 glucosaminoglycan(GAG) 분포는 $\mathrm{AE}$ 군 에 비하여 $\mathrm{AOF}$ 군에서 증가하였고, $\mathrm{OCN}$ 양성반응과 $\mathrm{OPG}$ 양성반응은 증가하였으며, $8-\mathrm{OHdG}$ 양성반응, RANKL 양성반응, MMP-3 양성반응은 감소하였다.

다음으로 盛智仁이 근위축의 개선에 미치는 영향 에 대한 실험을 진행한 결과, 대퇴사두근의 근육퇴화 에 따른 근육속막(endomysium)내 근섬유의 소실이 $\mathrm{AE}$ 군에 비해 $\mathrm{AOF}$ 군에서는 감소하였고, caspase-3 양성반응과 $8-\mathrm{OHdG}$ 양성반응, $\mathrm{p}-\mathrm{IkB}$ 양성반응도 감 소하였으며, Myo-D 양성반응은 증가하였다.

위의 결과를 종합하면, 盆智仁은 뼈의 형성을 증 가시키고 뼈의 소실을 감소시킴으로써 골다공증을 개선하는 것으로 생각되며, 근육의 소실 감소 및 근육생성 증가, 산화스트레스 및 근막내 염증을 감 소시킴으로써 근위축을 개선하는 것으로 생각된다. 이상의 결과를 통해 益智仁이 노화로 인한 근골격 계 이상인 골다공증과 근위축을 모두 개선시키는 효과를 가진다는 사실을 알 수 있다.

\section{감사의 글}

이 논문은 2018학년도 세명대학교 교내학술연구 비 지원에 의해 수행된 연구임.

\section{參考文獻}

1. Sherwood L. Human Physiology. $9^{\text {th }}$ ed. Seoul:
Life science; 2016, p. 732, 787-8.

2. Translated by professors from national medical university. Review of medical physiology. $18^{\text {th }}$ ed. Seoul: Hanwoori; 2002, p. 67-70, 412.

3. Nader GA. Molecular determinants of skeletal muscle mass: getting the "AKT" together. Int $J$ Biochem Cell Biol 2005 Oct:37(10):1985-96.

4. Ehrenborg E, Krook A. Regulation of skeletal muscle physiology and metabolism by peroxisome proliferator-activated receptor delta. Pharmacol Rev 2009 Sep;61(3):373-93.

5. Frontera WR, Ochala J. Skeletal muscle: a brief review of structure and function. Calcif Tissue Int 2015 Mar;96(3):183-95.

6. Orwoll ES, Oviatt SK, McClung MR, Deftos LJ, Sexton G. The rate of bone mineral loss in normal men and the effects of calcium and cholecalciferol supplementation. Ann Intern Med 1990 Jan 1;112(1):29-34.

7. Won HS. Age-related changes in body growth, muscle protein content and cellular-mediated immunity and rats fed stock diets. Korean $J$ food and Nutr 1991;4(2):133-9.

8. Rosenberg IH. Sarcopenia: origins and clinical relevance. $J$ Nutr 1997 May;127(5 Suppl): 990S-991S.

9. Korean Journal of Bone metabolism. Physicians guide for diagnosis \& treatment of osteoporosis. 2008.

10. Kwan H, Kim SB. Aging and sarcopenia. $J$ Korean Geriatr Soc 2007;11(2):55-9.

11. Choi SR. A study on climacteric women's risk of osteoporosis. The Graduate School of Public Administration, Hanyang university: Dept. of Nursing Administration 2002.

12. Hughes VA, Frontera WR, Wood M, Evans WJ, Dallal GE, Roubenoff R, et al. Longitudinal 
muscle strength changes in older adults: influence of muscle mass, physical activity, and health. $J$ Gerontol A Biol Sci Med Sci 2001 May; $56(5): B 209-17$.

13. Dutta C. Significance of sarcopenia in the elderly. J Nutr 1997 May;127(5 Suppl) :992S-993S.

14. Kum CJ, Cho CY, Lim JM, Song DU, Kim JH, Lee BN, et al. Effects of Yoohyangheukho-dan on osteoporosis induced by ovariectomy in rats. JKMR 2014 July;24(3):29-37.

15. Han SG, Kim DC. Anti-climacterium effects of Gagamguibiondam-tang in ovariectomized rats. $J$ Korean Obstet Gynecol 2017;30(4):18-44.

16. Cho SY, Kim DC. Anti-osteoporotic Activity of Gojineumja Aqueous Extracts on the Ovariectomized Mice. J Korean Obstet Gynecol 2018:31(4):16-38.

17. Cho CY, Kim EY, Kim DH, Kim MB, Kim SB, Yang KJ, et al. Effects of Bia-hwan (Féiér-wán) on the Ovariectomized Rat Model of Osteoporosis. JKMR 2017 July;27(2):19-27.

18. Cruz-Jentoft AJ, Landi F, Topinková E, Michel JP. Understanding sarcopenia as a geriatric syndrome. Curr Opin Clin Nutr Metab Care 2010 Jan;13(1):1-7.

19. Kim JY, Song YS. East-West medical examination of osteoporosis. $J$ of Oriental Rehabiliation Medicine 1996;6(1):293-315.

20. Rehabilitation Medicine Science Class at National Oriental Medicine College. Rehabilitation Medicine Science. Seoul: Seowondang; 1995, p. 149-281.

21. Medical College of Nanjing University of Traditional Chinese Medicine. Interpretation of the Yellow Emperor's Internal Classics. Shanghai: Shanghai Science and Technology Press; 1983, p. 4-5.

22. Kim JH, Kim YS, Lee SH, Choi G, Jeong SI, Ju YS. Chemical components of herbal medicines in Ungok herbology. $2^{\text {nd }}$ ed. Jeonju: Woosuk press; 2016, p. 236.

23. Lee HO. Renoprotective effect of Alpiniae oxyphyllae Fructus on ischemia/reperfusion-induced acute renal failure in rats. Professional Graduate school of Oriental Medicine, Wonkwang university: Dept. of Herbal resources 2009.

24. Park SY. The relaxation effects of Alpiniae Oxyphyllae Fructus on isolated corpus cavernosum smooth muscle. Kor $J$ Herbol 2015;30(4):61-9.

25. Ha H, Shim KS, Kim T, Lee CJ, Park JH, Kim HS, et al. Water extract of the fruits of Alpinia oxyphylla inhibits osteoclast differentiation and bone loss. BMC Complement Altern Med 2014 Sep 23;14:352.

26. Cruz-Jentoft AJ, Baeyens JP, Bauer JM, Boirie Y, Cederholm T, Landi F, et al. Sarcopenia: European consensus on definition and diagnosis: Report of the European Working Group on Sarcopenia in Older People. Age Ageing 2010 Jul;39(4) :412-23.

27. Prado CM, Wells JC, Smith SR, Stephan BC, Siervo M. Sarcopenic obesity: A Critical appraisal of the current evidence. Clin Nutr 2012 Oct; 31(5) : 583-601.

28. Rossi P, Marzani B, Giardina S, Negro M, Marzatico F. Human skeletal muscle aging and the oxidative system: cellular events. Curr Aging Sci 2008 Dec;1(3):182-91.

29. Choi WH. Medical treatment of osteoporosis: non-hormonal therapy. Hanyang Journal of Medicine 2002 Mar:22(1):19-26.

30. Lim SK. The recent trend in osteoporosis research. Biochemistry News 2002;22(3):207-6.

31. Cortez-Cooper MY, Anton MM, Devan AE, Neidre DB, Cook JN, Tanaka H. The effects of strength training on central arterial compliance in middle-aged and older adults. Eur $J$ Cardiovasc 
Prev Rehabil 2008 Apr;15(2):149-55.

32. Lindahl U, Höök M. Glycosaminoglycans and their binding to biological macromolecules. Annu Rev Biochem 1978;47:385-417.

33. Varki A, Cummings RD, Esko JD, Freeze HH, Stanley P, Bertozzi CR, et al. Essentials of Glycobiology. 2nd ed. Newyork: Cold Spring Harbor Laboratory Press; 2009.

34. Castor CW. Connective tissue activation. V. The flux of connective tissue activating peptide during acute inflammation. $J$ Lab Clin Med 1973 Jan;81(1) :95-104.

35. Hauschka PV. Osteocalcin: the vitamin K-dependent Ca2+-binding protein of bone matrix. Haemostasis 1986 ;16(3-4) :258-72.

36. Beckman KB, Ames BN. The free radical theory of aging matures. Physiol Rev 1998 Apr;78(2) :547-81.

37. Woessner JF Jr. Matrix metalloproteinases and their inhibitors in connective tissue remodeling. FASEB J 1991 May;5(8):2145-54.

38. Shingleton WD, Ellis AJ, Rowan AD, Cawston TE. Retinoic acid combines with interleukin-1 to promote the degradation of collagen from bovine nasal cartilage: matrix metalloproteinases-1 and -13 are involved in cartilage collagen breakdown. J Cell Biochem 2000 Sep 14;79(4): 519-31.

39. Metcalf KS, Selby PJ, Trejdosiewicz LK, Southgate J. Culture of ascitic ovarian cancer cells as a clinically-relevant ex vivo model for the assessment of biological therapies. Eur $J$ Gynaecol Oncol 1998;19(2):113-9.

40. Ishido M, Kami K, Masuhara M. In vivo expression patterns of $\mathrm{MyoD}, \mathrm{p} 21$, and $\mathrm{Rb}$ proteins in myonuclei and satellite cells of denervated rat skeletal muscle. Am $J$ Physiol Cell Physiol 2004 Aug;287(2):C484-93. 